essential before we can move in the matter-namely, voltage, ampèrage, wattage, time, and frequency. I have already referred to voltage, ampèrage, and frequency, and I have generally, if not always, stated the time; but why wattage as a fifth factor if we already have the voltage and the ampèrage? and what does Dr. Bowie mean by saying that wattage must be based on ampèrage since it is the product of voltage and ampèrage? Again, in autocondensation, which is the mode of application, I have been considering what authority has Dr. Bowie for saying that little or no current passes through the body, though an apparently high current was being registered in the milliampèremeter in series with the body? What means does he suggest for testing this? And let me remind him that no one has said that any current passes through the body. The current is not passing through but passing into and out of the body, and I have shown in my paper that the current loses force and quantity on its way into the body. It is a current in the meter but a capacity in the body. $\mathrm{He}$ evidently finds it difficult to get low-tension phenomena out of his mind. We are not dealing with closed circuits here. This very error, however, ought to have prevented him from saying that a body through which a current is passing may be getting almost no current regardless of the current which a milliampèremeter in series with it was registering. When I come to his remarks on the drop of potential observed by me when carrying out my experiments I at first hope that we are now on common ground; and, since I attach considerable importance to this part of my thesis, I should have been pleased to get from him some practical criticism of it. Instead of this, however, what he gives me is a mere theoretical contradiction. So I do join issue with him when he "respectfully submits that this is impossible." Is it possible that he has made this statement without having tried the experiment for himself ?

Dr. Bowie states that " no relation exists between the resistance of the body and the tension of the current on the spinthermeter." I have stated as a fact that, whilst this anto-condensation current is being applied, the difference of potential between, say, the hand and the axilla may exceed the equivalent of a spark-gap of two millimetres. Has Dr. Bowie tested this which I have declared to be a fact? If not, he surely might have done so and given us the benefit of his experience. That this difference of potential does not arise from ohmic resistance alone is, I think, true; but I should like to have Dr. Bowie's explanation of it if "resistance bears no relation to the potential difference." Does he think this resistance is a small matter? I have measured it with dry metallic electrodes as used in auto-condensation and found it to be vastly greater than I had suspected to be possible. I fear that much of what follows in Dr. Bowie's letter is too involved for me to be able to follow it Either he has failed to grasp my meaning or $I$ fail to grasp his. Let me say again, bowever, that I would rather he had stated not what he thought should be but what be really found to be the case. This is especially to be desired where he disputes the accuracy of my statement as to the fall of potential due to the passage of the current along a copper wire 25 feet long and of low ohmic resistance. He fails to see that mere ohmic resistance, unless enormous in amount, exercises practically no control on these high poten tial oscillations. Whether distance or the necessary bending of the wire on itself on account of the limited space in $\mathrm{my}$ room is the cause of the fall of potential I know notpossibly both may be; but certainly ohmic resistance has here nothing to do with it. Surely Dr. Bowie fails to see that he is giving himself away when he says: "Further, it is necessary that the electrodes be kept at the normal temperature of the body, otherwise no accurate records can be made, and this is particularly the case when observations are being taken regarding the increase of temperature due to these currents" ; for if the electrodes had first been warmed to the temperature of the hands the rise in the temperature of the forearm would have been just so much greater, and thus my contention would have been strengthened. My object in recording the temperature of the room and delaying the application of the current in these thermic experiments till from 30 to 40 minutes had elapsed after the patient, bad been placed on the couch was to secure as much accuracy as possible. Dr. Bowie attempts to reply to my question No. 1 in a very offhand manner. But when he says that his "answer to this is, as the voltage is increased a cor. responding fall in current will take place," he is evidently failing to note what I said on this point-namely, that I found from experiment that "the same quantity of current is obtainable from the same apparatus by a different arrangement of solenoid and spark gap, though there might be a different amount of potential difference to earth."

If Dr. Bowie is prepared to apply to the body 400 watts, made up of five ampères at a voltage of 80 , all I have to say is that I should not like to be the victim of this experiment. But how, I may ask, is he to obtain a current of five amperes through the body from a voltage of 80 or 100 , since, as in tho Apostoli treatment, it is difficult to obtain a twentieth part of this current from a voltage not much less? I am thus prepared to challenge his statement, though I am not prepared to have my "body subjected" to the trial, even with the reward of setting the question at rest. Finally, is Dr. Bowie willing to join the scientific investigation committee which I have proposed and which he says he approves of ? I trust he is - that is, of course, on the understanding that he has already done some work in high-frequency treatment. In that event some real gain may come out of it. I am, Sirs, yours faithfully.

Glasgow, August 10th, 1907. SAMUEL SLOAN.

\section{NATIONAL LENDING LIBRARY FOR THE BLIND.}

To the Editors of THE LANCET.

SIRs, - Will you kindly insert an appeal on behalf of the above most useful and much needed institution as it is in urgent need of funds to carry on the work? It is practically the only lending library for the blind for the whole of Great Britain. There are 900 direct readers, and about 900 more are reached through various institutions, to which books are sent. There are 40,000 blind persons in Britain! These could all be reached had the library a larger income. Each volume costs $15 s$. to produce. Owing to the bulkiness of the volumes, as a result of the raised type, the space needed for storage is great, and a new building is absolutely required in which the 8500 volumes now in stock can be properly arranged, quickly found, and despatched througb the post at "special rates," thanks to the kindness of the Hon. Sydney Buxton, Postmaster-General. The books are printed, some in the "Moon type," the rest in the "Braille type." An annual subscription of two guineas entitles a subscriber to nominate a poor reader who without the solace of books leads a sadly pitiful life in his sightless condition. We need $£ 200$ per annum more in subscriptions to carry on the work and far more than that $\mathrm{su} m$ in donations to enlarge the necessary premises and extend the nsefulness of the lending library. Would that some wealthy man or woman might be moved by pity to purchase a site, build really saitable premises, and provide a fund for the maintenance of the building. The library was opened in 1882 by the late Mrs. Dow and the late Miss Martha Arnold, and was incorporated as a " charitable institution" in 1898. H.R.H. Princess Louise, Duchess of Argyll, is President, the patrons are the Bishnp of London, the Bishop of Stepner, the Bishop of Southwark, the Duchess of Marlborough, the Earl of Kilmorey, and other distinguished persons. Full details concerning the library may be obtained from the Secretary, Miss E. W. Austin, National Lending Library for the Blind, 125, Queen's-road, Bayswater, W., to whom cheques and postal orders may be sent.

August 19th, 19007.

I am, Sirs, your obliged servant,

\section{A CASE OF PYREXIA OF UNCERTAIN ORIGIN.}

To the Editors of THE LANCET.

Sins,-Can you find room for the account of the following case in order that members of the profession may offer suggestions as regards diagnosis?

A female child, three and a half jears old, was brought to my consulting-room on the morning of August 6th on account of "feverishness" during the night. I ex*mined the case carefully and, apart from a temperature of $100^{\circ} \mathrm{F}$. could find no physical signs of disease in any of the organs. The throat was clear but the bowels were confined. I pre. scribed grain doses of calomel in the form of sweets and saw the patient again in the evening of the same day. The temperature had then risen to $101^{\circ}$. I gave her a saline mixture and saw her again two mornings later (Angust 8th), when 
the temperature was again $100^{\circ}$, and as the bowels had still not been opened I ordered a little carbonate of magnesia. On the 9th I saw her again, when the temperature had risen to $101^{\circ}$ again, and as the bowels were still confined I ordered grain doses of hydrargyrum cum creta. On the 10th the temperature rose to $102^{\circ}$. I began to suspect typhoid fever and treated her on those lines. I ordered an enema and the day after-viz., August 11th-the child had a good opening and the temperature fell to normal. examined the stools and although they looked somewhat pea-soupy in colour they were certainly not distinctive and not very offensive.

Although the temperature fell to normal and the child seemed much better I again made a very careful examination, still bearing in mind a possibility of typhoid fever (on account of the stools and the somewhat apathetic appearance of the child), but could not find any trace of that disease. The spleen was not palpable nor was its percussion area enlarged, and there was no tenderness in that region The tongue was certainly not characteristic and the pulse was not dicrotic. There were no rose spots to be seen; although it being only the sixth day of illness it was perhaps still somewhat too early to expect them. There was slight congestion of the lungs and I therefore suspected a hidden pneumonia or acute miliary tuberculosis, although the breathing was not of the pneumonic type and there were no other symptoms or signs to suggest any lung mischief. The child complained of some headache, but there were no other signs whatsoever of any cerebral or meningeal trouble. There was no squint, no retraction of the head, no Kernig's sign, and an ophthalmoscopic examination gave an entirely negative result. The ears and nose were examined, but absolutely nothing abnormal could be discovered. The apathetic appearance and somewhat drowsy condition of the child began to worry me a little, and therefore, when $I$ found on the next day, the 12th, that the temperature had again risen to $102^{\circ}$, I called into consultation Dr. Cecil Wall. In spite of the most careful, prolonged, and very searching examination no definite conclusion could be arrived at, all signs being absolutely negative, although this was already the seventh day of the illness. It was decided to watch the case till the tenth day and that I should then examine the blood for Widal's reaction. The consultation was held at 1 P.M. and at 4 P.M. I saw the little patient again, when her face was extremely flushed, her lips were tremulous, and she was plucking at the bed-clothes. The temperature was then $106^{\circ} 4^{\circ}$. I immediately telephoned to the consultant to come to see the child again, but before he arrived the patient died from collapse. No post-mortem examination was made.

The case presents two points of interest. Firstly, What could have been its nature? Secondly, assuming even that it was typhoid fever why should the child have died so suddenly from hyperpyrexia and collapse when only a few hours ago there appeared to be every prospect of a good recovery?

I am, Sirs, yours faithfully,

London, E., August 16th, 1907. M. Feldman.

\section{AN ASSOCIATION OF SHIP SURGEONS.}

To the Editors of THE LANCET.

SiRs,-In answer to many letters which I received con cerning my letter in your issue of August 17th may I be allowed further space to say on behalf of the B.S.S.A. (British Ship Surgeons Association) which is being formed that its aims are :-Firstly, to improve the "status" of sbip surgeons. Secondly, to issue a ship surgeons' gazette monthly, in which will be published "dissertations" on diseases peculiar to sea-going persons. Members will be expressly invited to narrate their experiences and views concerning the treatment of such affections as sea-sickness, \&c. A special article on "Marine Hygiene" will appear in each issue. Thirdly, to provide a medium for advertisement of "vacant posts" and " posts wanted."

The way in which it is proposed to improve the "status" of medical officers will be discussed at length later, when it is hoped that members will forward suggestions on the proposition in question. That there is need for this movement there can be very little doubt, judging from the "pay" of ships' medical officers, which does not compare favourably with that of surgeons holding equally responsible positions ashore. A committee will be formed of 12 past and present ship surgeons, six "past" and six "present." The six senior surgeons of the leading shipping companies in Great Britain will be asked to stand as the six present members.
The joint positions of honorary secretary and treasurer will be filled pro tem. by myself until it is convenient for the committee to fill the "posts." The annual subscription (to include monthly gazette) is proposed to be $10 \mathrm{~s} .6 d$. per member, which, however, is not to be forwarded until further notice. It is hoped that all medical men eligible for membership will come forward and render all the assistance possible in the formation of this much needed association. Applications for membership and other communications will be gratefully received by Yours faithfully,

$$
\text { G. METCALFE-SHARPE, }
$$

Late Surgeon $P$. and O. and Cunard Steamship Companies. Angram Hospital, Middlesmoor, Leeds, August 19th, 1907.

\section{THE TREATMENT OF TUBERCULOSIS AND LEPROSY.}

\section{To the Editors of THE LANCET.}

SIRs, - In a preliminary note on the Successful Treatment of Tuberculosis and Leprosy (published in THE LANCET of April 13th and 20th) I suggested the possibility of converting toxins into antitoxins by oxidising bacterial products with the help of tannic acid and the natural vegetable ferments-oxydases, \&c. Will you permit me to draw your attention and the attention of your readers to an abstract of a paper which appeared in the British Medical Journal of July 6th? I refer to the Epitome, p. 4, No. 11, "The Artificial Preparation of Therapeutic Serums." It would appear that Czajkowski successfully carried out the suggestion 1 made, only using the oxidising ferments of the liver and spleen in place of vegetable ferments.

I am, Sirs, yours faithfully,

Somerset Strand, Cape Colony, July 29th, 1907. S. F. WERNICH.

\section{THE TREATMENT OF INEBRIETY. To the Editors of THE LANCET.}

Sins, - I send for publication an account of my experience as medical superintendent of the Dadson Nursing Home for Inebriates in Norwich which has been in existence for just two years.

The treatment I have adopted has been a short one of usually four weeks and the results obtained on both men and women have been highly satisfactory. Statistics in a matter of this sort are of no great value but $I$ take the first 50 cases, all of which were treated over a year ago and most of whom have been traced. These cases were all treated on somewhat similar lines and an account of one typical case will show the system which I think should have the consideration of those who have cases of chronic alcoholism amongst their patients.

A man, aged 47 years, entered the home on August 3rd, 1905; he had been a chronic alcoholic for years and had a distinct family history of hereditary alcoholism. I allowed him to have a certain amount of his favourite beverage, as he was drinking heavily on admission, and started him at once on one teaspoonfal dose with about two ounces of water added, every two hours from 9 A.M. till 9 P.M., of the following tonic: Ammon. chlor., gr. i. ; aloin, gr.ii.; tr. cinchon. co., 3 iii. ; viburnum cordial, $\zeta$ i. Being in a shaky condition I found that an occasional dose of a mixture composed of ammon. chlor., tinct. cinchon. co., viburnum cordial, tr. capsici, and ext. kolæ liq. was very beneficial. I also gave him four times a day at intervals of four hours five minims of the following hypodermic injection: Daturinæ sulph., gr. i.; strych. sulph., gr. ii. ; acid. boric., gr. v. ; aq. dist., Z iv. During the first ten days I increased the injection gradually to double this quantity, no unfavourable symptoms being present. I am of opinion that datur. sulph. is much better than atropine, patients suffering far less from their eyes and complaining less of dryness and parched throat.

The injections and tonics were continued for three weeks and during the fourth week of treatment I reduced the number of tonics and number and quantity of injections. until at the end of the fourth week, i.e., the last day of treatment, he received only two doses of tonic and one fiveminim dose of injection. Insomnia was treated by means of veronal.

This man had perfect freedom during his stay in the home. After a few days his desire for alcoholic beverages disappeared and by the end of the first week he was practically normal. His brain began to be active and he was anxious to have occupation. He went straight back to his 